\title{
PENERAPAN AKUNTANSI PEMBIAYAAN MUDHARABAH BERDASARKAN PSAK NO. 105 PADA BANK BNI SYARIAH KANTOR CABANG MIKRO KOTA PAREPARE'
}

\author{
Darmawan $^{1}$ \\ Abdul Hamid ${ }^{2}$ \\ ${ }^{1}$ Dosen Program Studi Akuntansi, Fakultas Ekonomi Universitas Muhammadiyah \\ ${ }^{2}$ Dosen Sekolah Tinggi Agama Islam Negeri (STAIN) Parepare \\ Email: darmawan8387@gmail.com, abdulhamid29091972@gmail.com
}

\begin{abstract}
The research conducted focused on the application of mudharabah financing accounting based on PSAK No. 105. The problem raised in this study is how the application of mudharabah financing accounting based on PSAK No. 105 at Bank BNI Syariah in the Parepare City Micro Branch Office. The purpose of this study was to determine the application of mudharabah financing accounting based on PSAK No. 105 at Bank BNI Syariah in the Parepare City Micro Branch Office. This research conducted descriptive qualitative with comparative approach The results of the study stated that Bank BNI Syariah Micro Branch Office in the City of Pareparep had not fully implemented mudharabah financing accounting based on PSAK No. 105 due to the lack of product provision provided by the center and the type of financing used is mudharabah financing made from the customer (shahibul maal) to the Bank (Mudharib).
\end{abstract}

\begin{abstract}
Abstrak: Penelitian ini berfokus pada penerapan akuntansi pembiayaan mudharabah berdasarkan PSAK No. 105. Masalah yang diangkat dalam penelitian ini adalah bagaimana penerapan akuntansi pembiayaan mudharabah berdasarkan PSAK No. 105 pada Bank BNI Syariah Kantor Cabang Mikro Kota Parepare. Adapun tujuan dari penelitian ini adalah untuk mengetahui penerapan akuntansi pembiayaan mudharabah berdasarkan PSAK No. 105 pada Bank BNI Syariah Kantor Cabang Mikro Kota Parepare. Metode yang digunakan dalam penelitian ini adalah deskriptif kualitatif dengan menggunankan pendekatan kompratif. Hasil penelitian menyatakan bahwa Bank BNI Syariah Kantor Cabang Mikro Kota Pareparep belum Sepenuhnya menerapkan akuntansi pembiayaan mudharabah berdasarkan PSAK No. 105 disebabkan karena belum ada ketentuan produk yang diberikan oleh pusat dan adapun jenis pembiayaan yang digunakan adalah pembiayaan mudharabah yang dilakukan dari pihak nasabah (shahibul maal) ke Bank (Mudharib.
\end{abstract}

Kata Kunci : Akuntansi Pembiayaan, Mudharabah dan PSAK No.105 


\section{PENDAHULUAN}

\section{A. Latar Belakang Masalah}

Bank BNI Syariah merupakan salah satu usaha yang berlandaskan usaha sesuai dengan syarat Islam yang mengacu kepada Al-Qur'an dan hadits serta mengedepankan rasa keadilan dan transparansi dalam setiap transaksinya. Dengan adanya Bank BNI Syariah, masyarakat tidak perlu khawatir dengan pengelolaan dananya karena Bank BNI Syariah akan menyalurkan kepada sektor-sektor yang tidak bertentangan dengan syariah dan syiar Islam. Bank BNI Syariah akan mengutamakan penyaluran dananya kepada sektor rill yang diharapkan akan dapat menggerakkan perekonomian masyarakat, khususnya masyarakat muslim yang masih ragu dengan bunga bank. Bank dan lembaga keuangan syariah yang dapat menyimpan dana, meminjam dana, maupun hal-hal yang berkaitan dengan pembiayaan lainnya secara tenang telah banyak bermunculan.

Bank BNI Syariah Kantor Cabang Mikro Kota Parepare merupakan salah satu bank yang melakukan kegiatan menghimpun dana dan menyalurkan kembali kepada masyarakat tanpa

Merangkap dari masalah tersebut penulis berpikir bahwa penelitian ini dipandang perlu untuk dilakukan juga di Bank BNI Syariah Kantor Cabang Mikro Kota Parepare karena melihat pembiayaan mudharabah sangatlah penting dilakukan untuk membantu masyarakat muslim untuk menjalankan usahanya dan apakah pihak Bank BNI adanya sistem bunga. Bank BNI Syariah menerapkan sistem produk bagi hasil atau mudharabah. Mudharabah ini dapat dipergunakan untuk pembiayaan dan sebagai dasar untuk pendanaan seperti tabungan dan deposito.

Berdasarkan PSAK No. 105 (2007), mudharabah adalah akad kerjasama usaha antara dua pihak dimana pihak pertama (pemilik dana atau pihak bank) menyediakan seluruh dana, sedangkan pihak kedua (pengelola dana atau nasabah) bertindak selaku pengelolah dan keuntungan dibagi diantara mereka sesuai kesepakatan, sedangkan kerugian financial hanya ditanggung oleh pemilik dana.

Dikutip dari salah satu skripsi karya Sri Rokhlinasari (2011) dengan judul Penerapan pernyataan Standar Akuntansi keuangan menurut PSAK No 105 Pada pembiayaan mudharabah pada Bank BNI Syariah Cabang Cirebon, masih terdapat ketidaksesuaian terutama pada metode bagi hasil atau mudharabah yang diberikan Bank BNI Syariah dengan metode yang ada dalam PSAK No. $105^{1}$

Syariah telah menerapkan pembiayaan mudharabah di kota Parepare sesuai dengan syariah dan sesuai dengan ketentuan pencatatan akuntansi terutama pada metode bagi hasil mudharabah yang ada dalam PSAK No. 105.

Berdasarkan latar belakang di atas dan pernyataan yang ada, penulis 
tertarik untuk mengkaji dan meneliti judul yang sama tentang Penerapan Akuntansi Pembiayaan Mudharabah Berdasarkan PSAK No. 105 Pada Bank BNI Syariah Kantor Cabang Mikro Kota Parepare.

\section{B. Rumusan Masalah}

Bagaimana penerapan akuntansi pembiayaan mudharabah berdasarkan PSAK No.105 pada Bank BNI Syariah Kantor Cabang Mikro Kota Parepare?

\section{Tujuan Penelitian}

Untuk mengetahui penerapan akuntansi pembiayaan mudharabah berdasarkan PSAK No. 105 pada Bank BNI Syariah Kantor Cabang Mikro Kota Parepare.

\section{Manfaat penelitian}

Hasil penelitian ini diharapkan menjadi bahan kajian ilmiah pada ilmu-ilmu akuntansi khususnya mengenai penerapan akuntansi pembiayaan mudharabah berdasarkan PSAK No. 105.

\section{TINJAUAN PUSTAKA}

A. Bank konvesional dan Bank Syariah

Dikutip dari buku A. Muhammad Arafah (2012) dalam bukunya tentang bank dan lembaga keuangan lainnya menyatakan bahwa menurut (Kasmir: 2012) bank diartikan sebagai lembaga keuangan yang kegiatan usahanya adalah menghimpun dana dari masyarakat dan menyalurkannya kembali dana tersebut ke masyarakat serta memberikan jasa-jasa bank lainnya ${ }^{2}$.

Menurut H. Abdul Rahman Ghazaly dkk (2010:215) dalam bukunya "Fiqh dan Muamalat" menyatakan bahwa bank atau perbankan adalah lembaga keuangan yang usaha pokoknya memberikan kredit dan jasa-jasa dalam lalu lintas pembayaran serta peredaran uang dengan tujuan memenuhi kebutuhan kredit dengan modal sendiri atau orang lain ${ }^{3}$.

Bank non-islam (conventional bank) adalah lembaga keuangan yang fungsi utamanya untuk menghimpun dana yang kemudian disalurkan kepada orang atau lembaga yang membutuhkannya guna investasi (penanaman modal) dan usaha-usaha yang produktif dengan sistem bunga contohnya BNI, BRI, dan BCA.

Bank Islam (Bank Syariah) adalah suatu lembaga yang fungsi utamanya menghimpun dana untuk disalurkan kepada orang atau lembaga yang membutuhkannya dengan sistem tanpa bunga contohnya Bank Muamalat.

\section{B. Akuntansi}

Mudharabah

\section{Pembiayaan}

1. Akuntansi

Menurut Haryono Jusup (2011:4) dalam bukunya "Dasardasar Akuntansi jilid 1" menyatakan bahwa Akuntansi adalah sistem informasi yang mengukur aktivitas bisnis, mengelola data menjadi laporan dan mengomunikasikan hasilnya 


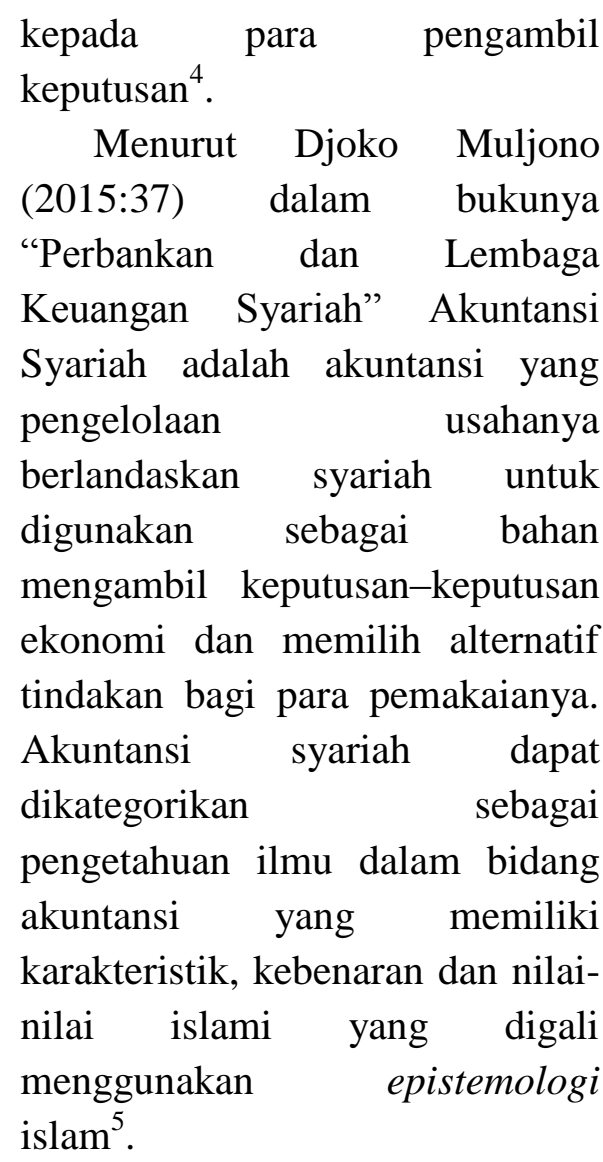

Tujuan akuntansi syariah adalah memberikan informasi secara lengkap untuk mengetahui nilai dan kegiatan ekonomi yang bertantangan, serta yang diperbolehkan secara syariah dan meningkatkan kepatuhan terhadap prinsip syariah dalam semua transaksi dan kegiatan usaha, menentukan hak dan kewajiban pihak-pihak yang berkepentingan dalam suatu entitas ekonomi syariah berlandaskan pada konsep kejujuran, keadilan, kebajikan, dan kepatuhan terhadap nilai-nilai dan etika bisnis islam.

\section{Pembiayaan}

Menurut Ismail (2011:105) dalam bukunya "Perbankan Syariah", pembiayaan merupakan aktivitas bank syariah dalam menyalurkan dana kepada pihak lain selain bank berdasarkan prinsip syariah. Penyaluran dana dalam bentuk pembiayaan didasarkan pada kepercayaan yang diberikan oleh pemilik dana kepada pengguna dana. Pemilik dana percaya kepada penerima dana bahwa dalam bentuk pembiayaan yang diberikan pasti akan terbayar. Penerima pembiayaan mendapat kepercayaan dari pemberi pembiayaan, sehingga penerima pembiayaan berkewajiban untuk mengembalikan pembiayaan yang telah diterimanya sesuai dengan jangka waktu yang telah diperjanjikan ${ }^{6}$.

Pembiayaan yang diberikan oleh bank syariah berbeda dengan kredit yang diberikan oleh bank konvesional. Dalam perbankan syariah, return atas pembiayaan tidak dalam bentuk bunga, akan tetapi dalam bentuk lain sesuai dengan akad-akad yang disediakan oleh bank syariah. Di dalam perbankan syariah, istilah kredit tidak dikenal karena bank syariah memiliki skema yang berbeda dengan bank konvesional dalam penyaluran dananya kepada pihak yang membutuhkan. Bank syariah menyalurkan dananya 
kepada nasabah dalam bentuk pembiayaan.

Menurut H. Veithzal Rivai dan Andria Permata Veithzal (2008:3) dalam bukunya "Islamic Financial Management”, istilah pembiayaan pada intinya berarti $I$ believe I trust, 'saya percaya' atau 'saya menaruh kepercayaan'. Perkataan pembiayaan artinya kepercayaan yang berarti lembaga pembiayaan selaku shahibul mal menaruh kepercayaan kepada seseorang untuk melaksanakan amanah yang diberikan ${ }^{7}$. Dana tersebut harus digunakan dengan benar, adil, dan harus disertai dengan ikatan dan syarat-syarat yang jelas dan saling menguntungkan bagi kedua belah pihak, sebagaimana firman Allah SWT dalam Qs. Al-Maidah (5): 1 yaitu :

Artinya: “...Hai orang yang beriman! Penuhilah akad-akad itu. Dihalalkan bagimu binatang ternak kecuali yang akan dibacakan kepadamu. (Yang demikian itu) dengan tidak menghalalkan berburu ketika kamu sedang mengerjakan haji. Sesungguhnya Allah menetapkan hukum-hukum yang di kehendakiNya...." (Qs. Al-Maidah (5):1)

Pembiayaan mempunyai peranan yang sangat penting dalam perekonomian. Secara garis besar, fungsi pembiayaan dalam perekonomian, perdagangan dan keuangan adalah sebagai berikut:

a. Pembiayaan dapat meningkatkan Utility (daya guna) dari modal atau uang atau suatu barang.

b. Pembiayaan meningkatkan peredaran dan lalu lintas uang.

c. Pembiayaan menimbulkan gairah usaha masyarakat.

d. Pembiayaan sebagai alat stabilisasi ekonomi.

e. Pembiayaan sebagai jembatan untuk peningkatan pendapatan nasional.

f. Pembiayaan sebagai alat hubungan ekonomi internasional.

$\begin{array}{ccc}\text { Menurut } & \text { Djoko } & \text { Muljono } \\ \text { (2015:77-78) } & \text { dalam } & \text { bukunya } \\ \text { "Perbankan } & \text { dan } & \text { Lembaga }\end{array}$
Keuangan Syariah", perbedaan antara pembiayaan mudharabah dengan penyertaan mudharabah antara lain :

a. Pembiayaan mudharabah ditunjukkan untuk membantu nasabah mendapatkan dana dalam rangka kegiatan usaha nasabah. Pembiayaan mudharabah dapat dilakukan oleh Lembaga Keuangan Syariah dan dapat dilakukan oleh nasabah. Bentuk pembiayaan tersebut adalah :

1) Pembiayaan mudharabah yang dilakukan oleh Lembaga Keuangan 
Syariah dapat diaplikasikan dengan akad lainnya seperti :
a) Mudharabah pada qardh,
b) Mudharabah pada ijarah,
c) Mudharabah pada sertifikat IMA.

2) Pembiayaan mudharabah yang dilakukan oleh nasabah kepada Lembaga Keuangan Syariah dapat diaplikasikan dengan akad wadiah yang dapat berbentuk Tabungan, Giro, Deposito, dan Simpanan, serta Investasi.

b. Penyertaan mudharabah ditunjukkan untuk melakukaan kerja sama antara pemodal dengan yang dibiayai. Aplikasi dari penyertaan mudharabah adalah pada musyarakah ${ }^{8}$.

\section{Mudharabah}

\section{a. Pengertian Mudharabah}

Menurut Djoko Moljono (2015:67) dalam bukunya "Perbankan dan Lembaga Keuangan Syariah", mudharabah adalah kerjasama antara dua atau lebih dari pihak pemilik modal (shahibul maal), yang mempercayakan sejumlah modal dengan kontribusi seratus persen $(100 \%)$ modal dari pemilik modal kepada pengelola (mudharib).
Menurut Abdullah Amrin (2006:133) dalam bukunya "Asuransi Syariah", Mudharabah adalah perjanjian di antara paling sedikit dua pihak. Mudharabah dapat dilakukan atas nama perseorangan atau lembaga, atau sebaliknya, lembaga dan seseorang. Pihak yang memiliki modal disebut Shahib al-mal atau rabb al mal. Orang/lembaga yang menerimanya dan menjalankan aktivitas usaha disebut pengusaha atau mudharib ${ }^{9}$.

Menurut Sofyan Syarif Harap (2004: 95-96) dalam bukunya "Akuntansi Islam", Mudharabah adalah kerja sama bank dengan pengusaha yang diyakini sepenuhnya.

Menurut Rozalinda (2016:205) dalam bukunya "Fikih Ekonomi Syariah", dijelaskan oleh Sayid Sabiq dalam bukunya Fiqh as-sunnah, secara bahasa, mudharabah diambil dari kalimat dharaba fil ardh yang artinya melakukaan perjalanan dalam rangka berdagang ${ }^{10}$.

\section{b. Jenis-Jenis Mudharabah}

Menurut Sutan Remy Sjahdeini (2014: 296) dalam bukunya, "Perbankan Syariah Produk-produk dan aspekaspek hukumya", ada 2 jenis mudharabah yaitu :

1) Al-mudharabah almuqayyadah

Disebut al-mudharabah al-muqayyadah atau 


$\begin{array}{lr}\text { mudharabah yang terbatas } \\ \text { apabila rabb-ul } & \text { mal } \\ \text { menentukan } & \text { bahwa } \\ \text { mudarib hanya } & \text { boleh } \\ \text { berbisnis dalam bidang } & \text { al- } \\ \text { tertentu. } & \\ \text { Al-mudharabah } & \text { muthlaqah } \\ \text { Disebut al-mudharabah } \\ \text { al-muthlaqah } \\ \text { mudarabah yang mutlak } \\ \text { atau tidak terbatas. }\end{array}$

\section{c. Bentuk-Bentuk Mudharabah}

Menurut Ismail (2011: 83) dalam bukunya "Perbankan Syariah" bentuk-bentuk mudharabah terbagi dalam 3 bentuk yaitu :

1) Investasi Mudharabah

2) Tabungan Mudharabah

3) Deposito Mudharabah ${ }^{11}$

\section{d. Berakhirnya}

Akad Mudharabah

Menurut Rozalinda (2016:217) dalam bukunya "Fikih Ekonomi Syariah", berakhirnya akad mudharabah disebabkan hal-hal sebagai berikut :
1) mudharabah tersebut mempunyai batasan waktu.
2) Salah satu pihak memutuskan mengundurkan diri.
3) Salah satu pihak meninggal dunia atau hilang akal.
4) Usaha yang dilakukan mengalami kerugian yang

mengakibatkan modal habis.

5) Akad mudharabah batal ketika shahibul maal atau mudharib murtad.

6) Salah satu syarat mudharabah tidak terpenuhi.

7) Pengelola dana tidak menjalankan amanah sebagai pengelolah usaha bila pengelola melakukan kesia-siaan $^{12}$.

\section{e. Bagi Hasil Dalam} Pembiayaan Mudharabah Menurut Ismail (2011:174) dalam bukunya "Perbankan Syariah", bagi hasil atas kerjasama usaha ini diberikan sesuai dengan nisbah yang telah dituangkan dalam akad mudharabah. Perhitungan mudharabah dibagi menjadi 2 yaitu :

\section{1) Revenue Sharing}

Perhitungan bagi hasil dengan menggunkan revenue sharing ialah berasal dari nisbah dikalikan dengan pendapatan sebelum dikurangi biaya.

\section{2) Profit / Loss Sharing}

Perhitungan bagi hasil dengan menggunakan profit/ loss sharing merupakan perhitungan bagi hasil yang berasal dari nisbah dikalikan dengan laba usaha sebelum 
dikurangi pajak penghasilan. Pendapatan kotor dikurangi dengan harga pokok penjualan, biaya-biaya sama dengan laba sebelum pajak. Laba usaha sebelum pajak dikalikan dengan nisbah yang disepakati, merupakan bagi hasil yang harus diserahkan oleh nasabah kepada bank syariah ${ }^{13}$.

\section{Pernyataan Standar Akuntansi Keuangan (PSAK) No.105}

\section{Pengukuran}

Pengukuran investasi

mudharabah adalah sebagai berikut (paragraf 13) :

a. Investasi mudharabah dalam bentuk kas diukur sebesar jumlah yang dibayarkan.

b. Investasi mudharabah dalam bentuk aset nonkas diukur sebesar nilai wajar aset nonkas pada saat.

Jika nilai investasi mudharabah turun sebelum usaha dimulai karena rusak, hilang atau faktor lain yang bukan kelalaian atau kesalahan pihak pengelola dana, maka penurunan nilai tersebut diakui sebagai kerugian dan mengurangi saldo investasi mudharabah (paragraf 14) jika sebagian investasi mudharabah.

\section{Pengakuan}

Jika investasi mudharabah melebihi satu periode pelaporan, penghasilan usaha diakui dalam periode terjadinya hak bagi hasil sesuai nisbah yang disepakati (paragraf 20). Kerugian yang terjadi dalam suatu periode sebelum akad mudharabah berakhir diakui sebagai kerugian dan dibentuk penyisihan kerugian investasi. Kerugian akibat kelalaian atau kesalahan pengelola dana dibebankan pada pengelola dana dan tidak mengurangi investasi mudharabah (paragraf 23). Bagian hasil usaha yang belum dibayar oleh pengelola dana diakui sebagai piutang (paragraf 24).

\section{Penyajian}

Pemilik dana menyajikan investasi mudharabah dalam laporan keuangan sebesar nilai tercatat (paragraf 36).

\section{Pengungkapan}

Pemilik dana mengungkapkan hal-hal terkait transaksi mudharabah tetapi tidak terbatas pada (paragraf 38) : Pengungkapan yang diperlukan sesuai dengan PSAK 101.

\section{METODE PENELITIAN}

\section{A. Lokasi Dan Waktu Penelitian}

Berdasarkan rancangan penelitian, lokasi penelitian dilaksanakan di Bank BNI Syariah Kantor Cabang Mikro di Jl. Lahalede Kota Parepare. Waktu yang dibutuhkan untuk penelitian kurang lebih 3 bulan terhitung dari 
bulan Februari sampai dengan bulan Mei 2017.

\section{B. Desain Penelitian}

Penelitan ini merupakan penelitian yang tergolong dalam penelitian deskriptif yang menggunakan pendekatan kualitatif didasarkan untuk memperoleh data yang bersumber dari Bank BNI Syariah Kantor Cabang Mikro Kota Parepare

\section{Defenisi Operasional Variabel}

Variabel penilitan ini adalah Pembiayaan mudharabah berdasarkan PSAK No. 105. Untuk lebih jelasnya dapat dilihat pada kolom defenisi operasional variabel berikut :

\section{Tabel 3.2}

\section{Defenisi Operasional Variabel}

\begin{tabular}{|l|c|c|}
\hline $\begin{array}{l}\text { Nama } \\
\text { Variabel }\end{array}$ & Penjelasan & Indikator \\
\hline
\end{tabular}


Berdasarkan data yang telah diperoleh, maka selanjutnya adalah dengan melakukan evaluasi atas data-data dan informasi yang diperoleh terkait penerapan akuntansi pembiayaan mudharabah berdasarkan PSAK No. 105 ditinjau dari 4 indikator yaitu pengukuran, pengakuan, penyajian, dan pengungkapan. Kategori tersebut dijadikan sebagai acuan dalam melakukan perbandingan antara penerapan akuntansi pembiayaan mudharabah berdasarkan PSAK No. 105 pada Bank BNI Syariah Kantor Cabang Mikro Kota Parepare.

Menurut Djoko Muljono (2015:77-78) dalam bukunya "Perbankan dan Lembaga Keuangan Syariah" menyatakan bahwa Pembiayaan mudharabah ditunjukkan untuk membantu nasabah mendapatkan dana dalam rangka kegiatan usaha nasabah. Pembiayaan mudharabah ${ }^{14}$.

Pada dasarnya, pengaplikasian yang dilakukan oleh Bank BNI Syariah Kantor Cabang Mikro Kota Parepare lebih tertuju kepada pembiayaan mudharabah yang dilakukan oleh nasabah ke lembaga keuangan syariah dimana Bank menjadi mudharib dan nasabah menjadi shahibul maal.

\section{Pengukuran}

Pemberlakuan akuntansi pembiayaan mudharabah menurut PSAK No. 105 dilihat dari sudut pengukuran adalah sebagai berikut :

a. Dana mudharabah yang disalurkan oleh pemilik dana diakui sebagai investasi mudharabah pada saat pembayaran kas atau penyerahan aset nonkas kepada pengelola dana.

b. Pengukuran investasi mudharabah adalah sebagai berikut :

1) Investasi mudharabah dalam bentuk kas diukur sebesar jumlah yang dibayarkan.

2) Invesatasi mudharabah dalam bentuk aset nonkas pada saat diukur sebesar nilai wajar aset nonkas pada saat penyerahan.

Dari hasil wawancara, Bank BNI Syariah Kantor Cabang Mikro Kota Parepare belum sepenuhnya menerapkan PSAK No. 105 karena investasi mudharabah dalam aset nonkas diukur sebesar nilai wajar aset nonkas pada saat penyerahan belum diterapkan karena Bank BNI Syariah Kantor Cabang Mikro Kota Parepare belum atau tidak menyediakan jasa aset nonkas yang berkaitan dengan pembiayaan mudharabah. 


\section{Pengakuan}

Pemberlakuan akuntansi pembiayaan mudharabah menurut PSAK No. 105 dilihat dari sudut pengakuan adalah sebagai berikut:

a. Jika nilai investasi mudharabah turun sebelum usaha dimulai disebabkan rusak, hilang atau faktor lain yang bukan kelalaian atau kesalahan pihak pengelola dana, maka penurunan nilai tersebut diakui sebagai kerugian dan mengurangi saldo investasi mudharabah.

b. Jika sebagian investasi mudharabah hilang setelah dimulainya usaha tanpa adanya kelalaian atau kesalahan pengelola dana, maka kerugian tersebut diperhitungkan pada saat bagi hasil.

c. Jika akad mudharabah berakhir sebelum atau saat akad jatuh tempo dan belum dibayar oleh pengelola dana, maka investasi mudharabah diakui sebagai piutang.

d. Jika investasi mudharabah melebihi satu periode pelaporan, penghasilan usaha diakui dalam periode terjadinya hak bagi hasil sesuai nisbah yang disepakati.

e. Kerugian yang terjadi dalam suatu periode sebelum akad mudharabah berakhir diakui sebagai kerugian dan dibentuk penyisihan kerugian invesatasi.

f. Kerugian akibat kelalaian atau kesalahan pengelola dana dibebankan pada pengelola dana dan tidak mengurangi investasi mudharabah.

g. Bagi hasil mudharabah dilakukan dengan menggunakan dua prinsip yaitu bagi laba atau bagi hasil.

Dari hasil wawancara, Bank BNI Syariah Kantor Cabang Mikro Kota Parepare belum sepenuhnya menerapkan PSAK No. 105. Dilihat pada point (a, c, dan e) di atas, Bank BNI Syariah Kantor Cabang Mikro Kota Parepare belum menerapkan hal tersebut karena belum ada keputusan dari kantor pusat mengenai hal tersebut. Pada point (f) dari hasil wawancara Kerugian akibat kelalaian atau kesalahan pengelola dana akan ditanggung bersama antara pemilik dan pengelola dana dan kerugian tersebut akan diperhitungkan pada pada bagi hasil. Bagi hasil 
menurut PSAK No. 105 yaitu bagi hasil mudharabah dilakukan dengan menggunkan dua prinsip yaitu bagi laba dan atau bagi hasil sedangkan dari hasil wawancara yang dilakukan di Bank BNI Syariah Kantor Cabang Mikro Kota Parepare menggunakan bagi hasil berdasarkan pendapatan atau disebut reveniu sharing.

\section{Penyajian}

Perlakuan akuntansi
pembiayaan menurut PSAK No. 105 dilihat dari sudut penyajian menyatakan bahwa pemilik dana menyajikan investasi mudharabah dalam laporan keuangan sebesar nilai yang tercatat.

Dari hasil wawancara dari sudut penyajian, Bank BNI Syariah Kantor Cabang Mikro Kota Parepare belum menerapkan PSAK No. 105 karena Bank BNI Syariah Kantor Cabang Mikro Kota Parepare belum mendapatkan keputusan mengenai wewenang dalam menyajikan laporan keuangan dari kantor pusat.

\section{Pengungkapan}

Pemberlakuan akuntansi pembiayaan mudharabah menurut PSAK No. 105 dilihat dari sudut pengungkapan adalah sebagai berikut : a. Pemilik dan pengelola dana mengungkapkan hal-hal yang terkait dengan transaksi mudharabah tetapi tidak terbatas.

b. Pengungkapan yang diperlukan sesuai dengan PSAK 101 dalam penyajian laporan keuangan.

Dari hasil wawancara, Bank BNI Syariah Kantor Cabang Mikro Kota Parepare belum sepenuhnya menerapkan PSAK No. 105 karena pengungkapan yang diperlukan sesuai dengan PSAK 101 dalam penyajian laporan keuangan belum disesuaikan dengan PSAK 101, melainkan disesuaikan berdasarkan keputusan Dewan Syariah Nasional.

\section{PENUTUP}

\section{A. Kesimpulan}

Dari hasil analisa dan pembahasan di atas, maka penulis dapat menarik suatu kesimpulan bahwa:

1. Bank BNI Syariah Kantor Cabang Mikro Kota Pareparep belum sepenuhnya menerapkan akuntansi pembiayaan mudharabah berdasarkan PSAK No. 105 karena belum ada ketentuan produk yang diberikan oleh pusat.

2. Adapun jenis pembiayaan yang digunakan adalah pembiayaan mudharabah yang dilakukan dari 
pihak nasabah (shahibul maal) ke Bank (Mudharib) dan pembiayaan murabahah di mana pembiayaan jenis ini lebih menguntungkan bagi pihak Bank.

3. Metode bagi hasil yang digunakan oleh Bank BNI Syariah kantor Cabang Mikro Kota Parepare belum sesuai dengan PSAK No. 105 karena metode bagi hasil yang digunakan oleh Bank BNI Syariah Kantor Cabang Mikro Kota Parepare menggunakan metode reveniu sharing yaitu pembagian hasil yang dihitung dari total pendapatan pengelolaan dana tanpa dikurangi dengan biaya-biaya yang dikeluarkan dalam pengelolaan dana tersebut. Sedangkan menurut PSAK No. 105 dalam paragraf 11 dijelaskan bahwa pembagian hasil usaha dapat dilakukan berdasarkan prinsip bagi hasil atau bagi laba.

\section{B. Saran}

Berdasarkan kesimpulan yang diperoleh dalam penelitian ini, maka diajukan saran-saran sebagai berikut

1. Sebaiknya, pembiayaan mudharabah dari pihak Bank (shahibul maal) ke nasabah (mudharib) juga diterapkan pada Bank BNI Syariah Kantor Cabang Mikro Kota Parepare.
2. Sebaiknya, dalam metode bagi hasil Bank BNI Syariah Kantor Cabang Mikro Kota Parepare menggunakan metode profit/ loss sharing dimana pendapatan atau bagi hasil yang diperoleh berasal dari keuntungan setelah dikurangi dengan biaya-biaya.

3. Sebaiknya, Bank BNI Syariah Kantor Cabang Mikro Kota Parepare dalam penerapan akuntansi pembiayaan mudaharabah juga menggunakan landasan PSAK No. 105 agar lebih terstandar.

\footnotetext{
1 Astuti, Dewi. Sri Rokhlinasari. 2015. Penerapan Pernyataan Standar Akuntansi Keuangan (PSAK) No. 105 Pada Pembiayaan Mudharabah di Bank BNI Syariah Cabang Cirebon. Artikel ini diakses pada hari Selasa tanggal 11 November 2016 pukul 06.30 WITA dari

http://www.google.co.id/serch?biw=360\&bih= 567\&ei=XjluWLOpNcXuvgSYyabwAQ\&q=p enerapan+pernyataan+standar+akuntansi+keua ngan+psak+105+pada+pembiayaan+Mudharab $\mathrm{ah}+\mathrm{di}+\mathrm{Bank}+\mathrm{BNI}+$ Syariah\&oqI=mobile-gwsserp

2 Arafah, Muhammad A. Bank dan Lembaga keuangan Lainnya ( Parepare, 2012)

3 Ghazali, Abdul Rahman. Dkk. Fiqh Muamalat. (Cetakan 1.Kencana: Jakarta, 2010), hal. 215

4 Jusup, Haryono. Dasar-dasar Akuntansi Jilid I (Edisi 1. Cetakan 1. Sekolah Tinggi Ilmu Ekonomi YKPN: Yogyakarta, 2011), hal 4

5 Muljono, Djoko. Perbankan dan Lembaga Keuangan Syariah (Edisi 1. ANDI: Yogyakarta, 2015), hal 37

6 Ismail. Perbankan Syariah (Cetakan 1. Kencana : Jakarta, 2011), hal. 105

7 Rivai, Veithzal H. dan Andria Permata Veithzal. Islamic Fianancial Management (Edisi 1. Cetakan 1. PT.RajaGrafindo Persada: Jakarta, 2008), hal. 3
} 


\footnotetext{
8 Muljono, Djoko, Perbankan dan Lembaga Keuangan Syariah, hal 77-78

9 Harahap, Sofyan Syafri, Akuntansi Islam (Edisi 1 Cetakan 4. PT. Bumi Aksara: Jakarta. 2004), hal. 67

${ }^{10}$ Rozalinda, Fikih Ekonomi Syariah (Edisi 1. Cetakan 1. PT.RajaGrafindo Persada. Depok : Jakarta, 2016), hal. 95-96

11 Ismail, Perbankan Syariah (Cetakan 1. Kencana : Jakarta, 2011), hal. 296

${ }^{12}$ Rozalinda, Fikih Ekonomi Syariah , hal. 217

${ }^{13}$ Ismail, Perbankan Syariah, hal. 174

14 Muljono, Djoko, Perbankan dan Lembaga Keuangan Syariah, hal. 77-78
}

\section{DAFTAR PUSTAKA}

Amrin, Adbullah. 2006. Asuransi Syariah. PT. Elex Media Komputindo Kelompok Gramedia: Jakarta.

Arafah, Muhammad A. 2012. Bank dan Lembaga keuangan Lainnya: Parepare.

Arikunto. 2006. Metode Pengumpulan Data. Artikel ini diakses pada hari Jumat tanggal 30 Desember 2016 dari http://sakalvin.blogspot.com.2013/ 04/metode-pengumpulan-data-dandaftar-pustaka=html? $\mathrm{m}=1$.

Astuti, Dewi. Sri Rokhlinasari. 2015. Penerapan Pernyataan Standar Akuntansi Keuangan (PSAK) No. 105 Pada Pembiayaan Mudharabah di Bank BNI Syariah Cabang Cirebon. Artikel ini diakses pada hari Selasa tanggal 11 November 2016 pukul 06.30 WITA dari http://www.google.co.id/serch?biw $=360 \& \mathrm{bih}=567 \& \mathrm{ei}=\mathrm{XjluWLOpNc}$ XuvgSYyabwAQ\&q=penerapan $+p$ ernyataan+standar+akuntansi+keu angan+psak+105+pada+pembiaya an+Mudharabah+di+Bank+BNI+S yariah\&oqI=mobile-gws-serp.

Djamal, Faturrahman. Haji .2012. Penyelesaian Pembiayaan Bermasalah Di Bank Syariah. Cetakan Pertama. Sinar Grafika: Jakarta.

Fadhila, Novi. 2015. Analisis Pembiayaan Mudharabah dan Murabahah terhadap Laba Bank Syariah mandiri. Jurnal Riset Akuntansi dan Bisnis Vol.15 No.1 Maret 2015. Aritikel ini diakses pada hari Kamis tanggal 20 Oktober 2016 pukul 15:39 WITA dari

http://jurnal.umsu.ac.id/index.php/ akuntan/article/download/427/pdf59.

Ghazali, Abdul Rahman. Dkk. 2010. Fiqh Muamalat. Edisi Pertama Cetakan 1.Kencana: Jakarta. 
Gustani, Blog. 2015. Pengertian Akuntansi Syariah. Artikel ini diakses pada hari Selasa 10 Januari 2017 pukul 20:30 WITA dari https://www.google.co.id/url?q=htt ps://gustani.blogspot.com/2015/07/ defenisi-akuntansi-syariah-html.

Harahap, Sofyan Syafri. 2004. Akuntansi Islam. Edisi 1 Cetakan 4. PT. Bumi Aksara: Jakarta.

Hasibuan, Malayu SP. H. 2007. Dasardasar Perbankan. Dikutip dari Skripsi Siti Nurlola Hidayat. Artikel ini diakses pada hari Minggu tanggal 20 Desember 2016 pukul 22:24 dari http://www.google.co.id/seacrh?q= jurnal+skripsi+siti+nurlola\&hl=i\& dbiw=1366\&bihpnud=nmv\&sourc $\mathrm{e}=\mathrm{inms} \& \mathrm{sd}=\mathrm{x} \& \mathrm{ved}$.

Ikatan Akuntansi Indonesia. 2007. Pernyataan Standar Akuntansi Keuangan. Tentang Akuntansi Mudharabah. Artikel ini diakses pada hari Minggu tanggal 20 Desember 2016 dari http://www.google.co.id/search?q= jurnal+PSAK+105+tentang+mudh araba\&Oq+jurnal+PSAK+105+ten tang+mudharabah\&aq=mobilegws-link.

Ismail. 2011. Perbankan Syariah. Cetakan 1. Kencana : Jakarta.

Jusup, Haryono. 2011. Dasar-dasar Akuntansi Jilid I. Edisi 1. Cetakan 1. Sekolah Tinggi Ilmu Ekonomi YKPN: Yogyakarta.
Mardani. 2014. Hukum Bisnis Syariah. Edisi Pertama. Cetakan 1. Kencana: Jakarta.

Muljono, Djoko. 2015. Perbankan dan Lembaga Keuangan Syariah. Edisi 1. ANDI: Yogyakarta.

Permata,Russely Inti Dwi. Dkk. 2014. Analisis Pengaruh Pembiayaan Mudharabah dan Musyarakah Terhadap Tingkat Profitabilitas (Studi Pada Bank Umum Syariah Yang Terdaftar di Bank Indonesia periode 2009 - 2012. Jurnal Administrasi Bisnis (JAB) Vol.12.No. 1 Juli 2014. Artikel ini diakses pada hari Selasa 15 November 2016 pukul 06:41 WITA dari http://administrasibisnis.studentjou rnal.ub.ac.id/index.php/jab/article/ viewfile/486/683.

Rivai, Veithzal H. dan Andria Permata Veithzal. 2008. Islamic Fianancial Management. Edisi 1. Cetakan 1. PT.RajaGrafindo Persada. Kepala Gading: Jakarta.

Rozalinda. 2016. Fikih Ekonomi Syariah. Edisi 1. Cetakan 1. PT.RajaGrafindo Persada. Depok : Jakarta.

Sari, Silpia Navita. 2012. Analisis Pengakuan dan Pengukuran Pada Pembiayaan Mudharabah Berdasarkan PSAK 105 (Studi Kasus Pada PT Bank Muamalat Indonesia Tbk.). Artikel ini diakses pada hari Rabu tanggal 16 November 2016 pukul 06:16 WITA dari

http://www.google.co.id./search?biw=3 $60 \&$ bin $=567 \&$ ei $=$ fuwtwksMntvASxntf wDO\&q=jurnal+tentang+pembiayaan+ 
mudharabah+psak+105+di+bank+mua malat+syariah\&oq=jurnaltentangpe $\& g$. $\mathrm{t}=$ mobile.gws.serp).

Sjahdeini, Sutan Remy. 2014. Perbankan Syariah_Produkproduk dan Aspek-aspek Hukumnya. Edisi 1 Cetakan 1. Kencana: Jakarta.

Sugiyono. 2014. Metode Penelitian Manajemen. Alfabeta: Bandung.

Sugiyono. 2015. Metode Penelitian Manajemen. Alfabeta: Bandung.

Suhendi, Hendi H. 2010. Fiqh Muamalah. Cetakan ke-6. PT. Rajagrafindo Persada: Jakarta.

Sutendi, Aldrian. 2009. Dikutip dari skripsi Nur Aini Rahman. Artikel ini diakses pada hari Minggu 20 Desember 2016 pukul 20:30 WITA dari http://repository.uinjkt.ac.id/dspac e/handle/123456789/1201.

Wahyu, Halimatus. Nur Hisamuddin. Agung Budi Sulistiyo. 2016. Analisis implementasi Pembiayaan Mudharabah pada PT Bank BNI Syariah Kantor Cabang Jember. Artikel Ilmiah Mahasiswa. Artikel ini diakses pada hari Kamis tanggal 28 Desember 2016 pukul 20:30 WITA dari

http://www.google.co.id./m?q=pdf+jur nal+tentang+skripsi+pembiayaan+mud harabah+berdasarkan+PSAK+105+Ban $\mathrm{k}+\mathrm{BNI}+$ Syariahh\&oqQaqs $=$ mobilegws_lite.

www. BNI Syariah.co.id. 